\title{
Elevating Cultural Rights Using International Criminal Law-The Asian Story
}

\author{
Raghavi VISWANATH* \\ Leiden Law School, The Netherlands \\ raghaviı125@yahoo.com
}

\begin{abstract}
Codified in Articles 27 and I 5(I)(a) of the International Covenant on Civil and Political Rights [ICCPR] and International Covenant on Economic, Social, and Cultural Rights [ICESCR], respectively, cultural rights are still read as distinct from linguistic and religious freedoms. The ICCPR vests cultural rights only in "persons belonging to minorities", instead of groups. This paper attempts to analyze the reasons for the deficiencies in the ICCPR/ICESCR cultural rights regimes. In so doing, it unpacks the implications of these deficiencies for three current conflicts in Asia-the alleged persecution of Rohingyas in Myanmar, Uighurs in China, and Kashmiri Muslims in India-which are replete with cultural rights violations. It then tests whether the richer culture-based jurisprudence in international criminal law can offer lessons for the recalibration of cultural rights under the ICCPR/ICESCR. In particular, whether such cross-fertilization can trigger the jurisdiction of alternative forums to enforce state responsibility for these violations.
\end{abstract}

"The best way to tear someone down is to tear down their culture, tear down everything that is important to them." I

In late December 20I9, the US threatened to destroy fifty-two cultural heritage sites in Iran. ${ }^{2}$ Academia immediately denounced the threat, penning timely reminders of the fact that the destruction of cultural heritage is a war crime in international criminal law. ${ }^{3}$ While cultural rights have taken centre-stage in Iran, they seem to be conspicuously missing from the civil and legal discourse in other parts of Asia.

* Advanced LLM in International Criminal Law Candidate, Leiden Law School (20I9-20); BCL (Oxon.), B.A., LL.B. (Hons.).

I. Prosecutorv. Ahmad Al Faqi Al Mahdi, Case No. ICC-or/ı 2-or/I 5, Witness MLI-OTP-P-o43 I (on file with the author).

2. "US and Iran Must Protect Cultural Sites, Says UNESCO” Al Jazeera (7 January 2020), online: $\mathrm{Al}$ Jazeera <https:/www.aljazeera.com/news/2020/oI/iran-protect-cultural-sites-unesco200I06I830I6546.html>.

3. Sara C. BRONIN, "Destroying Cultural Heritage Sites Is a War Crime" Los Angeles Times ( 5 January 2020), online: Los Angeles Times <https://www.latimes.com/opinion/story/2020-0I-O5/ iran-donald-trump-cultural-sites-war-crimes. 
Asia is currently experiencing a Grotian moment-in that it has finally succeeded in drawing the attention of international courts towards the systematic human rights violations by Asian governments. ${ }^{4}$ Amongst the many conflicts dividing Asia, three are of particular importance to this research.

First, the alleged persecution of the Uighur Muslims in China. After 9/II, the Chinese government began labelling Uighurs as potential terror threats. In recent years, reports claim that the government has been destroying mosques, confiscating religious material, and detaining Uighurs in "re-education" camps. ${ }^{5}$ In these camps, Uighurs are allegedly forced to denounce Islam, learn Mandarin, and chant the praise of the Chinese premier. ${ }^{6}$

Second, the Rohingya conflict. The Rohingyas are Bengali Muslims who have been at the receiving end of persecution by the Buddhist majority in the Rakhine State in Myanmar since the I960s. ${ }^{7}$ Buddhist nationalist groups have historically rejected the group's ethno-religious identity and have called for the boycott of Muslim shops, and the expulsion of Muslims from Myanmar. ${ }^{8}$ According to the UN Migration Agency, over 7I2,700 Rohingya have fled to Bangladesh since 20I7, and over I 2,800 Rohingya have been internally displaced. ${ }^{9}$

Third, the ongoing persecution of Kashmiri Muslims in India. In August 2019, the Indian Parliament constitutionally revoked the special status of Jammu and Kashmir in the Union of India. ${ }^{\text {IO }}$ Before the amendment, Jammu and Kashmir enjoyed certain constitutional privileges-in that it had its own penal code, ${ }^{\text {II }}$ and preferential

4. Situation in the People's Republic of Bangladesh/Republic of the Union of Myanmar, Decision Pursuant to Article I5 of the Rome Statute on the Authorization of an Investigation into the Situation in the People's Republic of Bangladesh/Republic of the Union of Myanmar, I4 November 2019, Case No. ICC-or/I9; Application of the Convention on the Prevention and Punishment of the Crime of Genocide (Gambia v. Myanmar), Order of 23 January 2020, I.C.J.

5. Amnesty International, "Joint Statement Calling for Xinjiang Resolution at the United Nations Human Rights Council” (4 February 20I9), online: Amnesty International <https://www.amnesty. org/download/Documents/ASAI7978920I9ENGLISH.pdf>.

6. Josh ROGIN, "Ethnic Cleansing Makes a Comeback-in China" The Washington Post (3 August 20I8), online: The Washington Post <https:/www.washingtonpost.com/opinions/global-opinions/ ethnic-cleansing-makes-a-comeback-in-china/20 I 8/o8/o2/5 5 f 73 fa 2-969 I-I I e8-8 Ioc5 fa70 5927 d 54_story.html>.

7. William A. SCHABAS, Nancie PRUDHOMME, and Joseph POWDERLY, "Crimes against Humanity in Western Burma: The Situation of the Rohingyas", National University of Ireland, Galway, Irish Centre for Human Rights (2010) at 25.

8. Report of the Detailed Findings of the Independent International Fact-Finding Mission on Myanmar, UN Human Rights Council, UN Doc. A/HRC/39/CRP.2 (20I8), at I66, para. 697, n. I 5 I I, "K-I I 2. Unofficial Translation of A Myo Pyaut Mhar Soe Kyaut Sayar”.

9. Kaladan Press Network, "Rape by Command: Sexual Violence as a Weapon Against the Rohingya" Kaladan Press (February 20I8), online: Kaladan Press <https://progressivevoicemyanmar.org/wpcontent/uploads/2018/02/RapebyCommandWeb3.pdf> at 9; Inter Sector Coordination Group, Situation Report: Rohingya Refugee Crisis, Cox's Bazar, United Nations Office for the Coordination of Humanitarian Affairs: Humanitarian Response (I November 20I8), online: UN OCHA: Humanitarian Response <https:/www.humanitarianresponse.info/sites/www.humanitarianresponse.info/files/documents/files/iscg_situation_report_I_nov_20I8.pdf >.

Iо. The Constitution (Application to Jammu and Kashmir) Order, 20I9.

I I. The Jammu and Kashmir State Ranbir Penal Code, I989. 
property laws. ${ }^{\mathrm{I} 2}$ The former state (now Union territory) had even recognized Urdu as its official language. ${ }^{\mathrm{I} 3}$ The 2019 amendment completely erased this special identity. ${ }^{\mathrm{I}}$ Further, in 2019, the Union government even revised the list of public holidays to remove the customary holidays of Kashmir. ${ }^{15}$

Admittedly, all these conflicts occur in different sociopolitical contexts. Yet, there is one thread of commonality that runs across all three conflicts. It appears that they are replete with instances of state-sponsored affronts to cultural rights (incidentally of Muslims)—whether it is through denial of the right to participate in cultural life, or erosion of language, or denying access to traditional homes. However, cultural rights are completely missing from the claims of accountability that have thus far been launched against the perpetrator states.

One reason for this may be that cultural rights are rather undertheorized in human rights discourse. ${ }^{16}$ As a result, the relevance of cultural rights is often in doubt. Albeit in varying forms and degrees, cultural rights find mention in Article 27 of the International Covenant on Civil and Political Rights [ICCPR] and Article I 5(I)(a) of the International Covenant on Economic, Social, and Cultural Rights [ICESCR]. ${ }^{17}$ However, per their current formulation in these treaties, cultural rights have limited scope. Notably, Article 27 of the ICCPR recognizes the right to culture as one amongst a group of rights enjoyed by persons belonging to minorities. Such a formulation has led the Human Rights Committee [HRC] to read culture as distinct from the minority's right to practise and profess the religion of their choice and the right to speak their own language. As a result, culture is implicitly limited. A similar interpretation is accorded to the right to participate in cultural life of the ICESCR. Article 27 of the ICCPR also uses limiting individualistic language by vesting cultural rights only on "persons" belonging to minorities, instead of the group as a whole. ${ }^{\mathrm{I} 8}$

The second, arguably more likely reason, is that there is no forum where the obligations to protect cultural rights can be enforced. While India, China, and Myanmar have ratified the ICECSR, none of these states have ratified the Optional Protocol to the ICESCR, which creates an individual state complaint mechanism. ${ }^{\mathrm{I} 9}$ The ICCPR

I2. “Decoding Centre's J-K Move on Article 370 in 9 Steps" Hindustan Times (6 August 20I9), online: Hindustan Times <https:/www.hindustantimes.com/india-news/decoding-centre-s-j-k-move-on-article-370-in-9-steps/story-VmKdC7c4HfTKDiROjzpdUI.html>.

I3. The Jammu and Kashmir Reorganization Act, 20I9, s. 47.

I4. Ibid., Fifth Schedule.

I 5. Government Order No. 25I-JK (General Administration Department) 20I9, annexure A.

I6. Athanasios YUPSANIS, "The Concept and Categories of Cultural Rights in International LawTheir Broad Sense and the Relevant Clauses of the International Human Rights Treaties" (2010) 37 Syracuse Journal of International Law and Commentary 207.

I7. International Covenant on Civil and Political Rights, I9 December I966, 999 U.N.T.S. I7 I, 6 I.L.M. 368 (entered into force 23 March I976), art. 27 [ICCPR]; International Covenant on Economic, Social and Cultural Rights, I6 December I966, 993 U.N.T.S. 3, 6 I.L.M. 360 (entered into force 3 January I976), art. I5(I)(a) [ICESCR].

I8. Francesco CAPOTORTI, “Are Minorities Entitled to Collective International Rights?” (I990) 20 Israeli Yearbook on Human Rights $35 \mathrm{I}$ at 353.

I9. Poma Poma v. Peru, Views of the Human Rights Committee, UN Doc. CCPR/C/95/D/I457/2006 (2009); UN Office of the High Commissioner, "Status of Treaties-Optional Protocol to the International Covenant on Economic, Social and Cultural Rights", online: UN Office of the High Commissioner <https://indicators.ohchr.org/> [Status of Ratification]. 
presents an even more dangerous prospect, given that both China and Myanmar have not ratified the Covenant itself. ${ }^{20}$ As a result, the internal enforcement forums under the Covenants are unavailable to victims.

In such a situation, it is useful to have recourse to other bodies of law, one of which is international criminal law. There is no doubt that international criminal law has its own limitations in that neither China nor Myanmar nor India has signed the Rome Statute. ${ }^{2 \mathrm{I}}$ So, the International Criminal Court [ICC] cannot exercise territorial jurisdiction over these violations. But this does not render international criminal law jurisprudence insignificant. This paper attempts to draw lessons from international criminal law jurisprudence to make a case for the recalibration of cultural rights in human rights law, in particular, the human rights regimes of the ICCPR and ICECSR. Parts I and II critically examine international criminal law jurisprudence to understand if its interpretation of cultural rights ought to be preferred, and why. Part III then attempts to import the value-oriented reading of culture into human rights law and unpacks its implications for the three Asian conflicts that are the subject of this study.

\section{INTERNATIONAL CRIMINAL LAW'S NELSONIAN EYE TO ECONOMIC, SOCIAL, AND CULTURAL RIGHTS}

In the immediate wake of their establishment, the International Criminal Tribunal for the former Yugoslavia [ICTY] and the International Criminal Tribunal for Rwanda [ICTR] struggled to reconcile the criminal law approach to favour the defendant (in dubio pro reo) with the victim-friendly human rights approach. In finding this balance, the tribunals displayed a marked reluctance towards attributing criminality to curtailments or violations of economic, social, and cultural rights [ECSRs].

There are definitional and structural reasons underlying this reluctance. First, ECSRs were quite loosely defined. They were, at best, aspirational or programmatic. ${ }^{22}$ This was seen as an affront to the principle of strict legality in international criminal law-according to which individuals could only be prosecuted for acts that were previously and clearly criminalized/outlawed.

Second, obligations to secure ECSRs are generally in the nature of obligations of result, and consequently, violations of ECSRs are characterized by a failure to act. However, international criminal law is conservative about criminalizing omissions. In fact, the Elements of Crimes of the Rome Statute notes that " $[t]$ he existence of

\footnotetext{
20. Status of Ratification, supra note I9.

2I. International Criminal Court, "The State Parties to the Rome Statute", online: ICC <https://asp.icccpi.int/en_menus/asp/states \% 2oparties/Pages/the \% 2ostates $\%$ 2oparties $\%$ 20to $\% 20$ the $\%$ 20rome\% 2ostatute.aspx>.

22. Michael J. DENNIS and David P. STEWART, "Justiciability of Economic, Social, and Cultural Rights: Should There Be an International Complaints Mechanism to Adjudicate the Rights to Food, Water, Housing, and Health?” (2004) 98 American Journal of International Law 462.

23. George P. FLETCHER and Jens David OHLIN, "Reclaiming Fundamental Principles of Criminal Law in the Darfur Case" (2005) 3 Journal of International Criminal Justice 539 at 56I.
} 
such a policy cannot be inferred solely from the absence of governmental or organizational action". ${ }^{24}$ This is not to say that international criminal law is completely averse to prosecuting omissions which have the same degree of criminal culpability. For instance, the Assembly of States Parties recently agreed to criminalize starvation in non-international armed conflicts as a war crime. ${ }^{25}$ Nonetheless, such acts have to be accompanied by a deliberate policy to encourage the crime. ${ }^{26}$ Therefore, many ECSR violations have been unaddressed.

Third, the reluctance is a direct consequence of the structural difference between human rights law and international criminal law. It is true that the individual is at the centre of both human rights law and international criminal law. However, the individual is situated differently in the two fields. ${ }^{27}$ Human rights places obligations on the state vis-à-vis the individual. Therefore, the individual is the rights-holder. International criminal law, on the other hand, identifies the individual behind the state with the intention of prosecuting them. Here, individuals are the duty-bearers and the rights-holders.

With the adoption of the Rome Statute, there is considerably less space for direct application of human rights in substantive criminal law. ${ }^{28}$ Nonetheless, international criminal law is still useful insofar as it makes an expressivist contribution towards acknowledging the socioeconomic and cultural dimensions of conflict. ${ }^{29}$

\section{BEST PRACTICES IN INTERNATIONAL CRIMINAL LAW}

The statutes of many international criminal tribunals contain crimes that are made up of serious violations of cultural rights. For instance, Article $3(\mathrm{~d})$ of the ICTY Statute codifies the war crime of seizure, destruction, or wilful damage to institutions dedicated to religion, charity, education, arts and sciences, historic monuments, and works of art and science. ${ }^{3 \circ}$ In the ICC architecture, Articles 8(2)(b)(ix) and (e)(iv) of the Rome Statute criminalize the destruction of cultural heritage in both international and internal armed conflicts. ${ }^{3 \mathrm{I}}$ Moreover, the ICTY, ICC, ICTR, Extraordinary Chambers in the Courts of Cambodia, and the Special Court for

24. Rome Statute of the International Criminal Court, I7 July I998, 2 I 87 U.N.T.S. 90, 37 I.L.M. I002 (entered into force I July 2002), art. 7 [Rome Statute].

25. Kevin Jon HELLER, "The Rome Statute's Flawed Amendment Regime-Starvation in NIAC Edition” Opinio Juris (7 December 20I9), online: Opinio Juris <http://opiniojuris.org/20I9/I 2/07/ the-rome-statutes-flawed-amendment-regime-starvation-in-niac-edition/>.

26. Elies Van SLIEDREGT, Individual Criminal Responsibility in International Law (Oxford: Oxford University Press, 20I2) at 54-7.

27. Larissa van den HERIK, "International Criminal Law's Blind Spot?" in Eibe RIEDEL, Gilles GIACCA, and Christophe GOLAY, eds., Economic, Social and Cultural Rights in International Law: Contemporary Issues and Challenges (Oxford: Oxford University Press, 2014), 343.

28. Rome Statute, supra note 24 , arts. 21, 22.

29. Louise ARBOUR, "Economic and Social Justice for Societies in Transition" (2007) 40 International Law and Politics I at I6.

30. Statute of the International Criminal Tribunal for the Former Yugoslavia, SC Res. 827, UN Doc. S/ RES/827 (I993), art. 3(d) [ICTY Statute].

3I. Rome Statute, supra note 24 , arts. $8(2)(\mathrm{b})(\mathrm{ix})$ and (e)(iv). 
Sierra Leone have jurisdiction over other crimes such as genocide and persecution which implicate cultural rights. ${ }^{32}$ Fortunately, these crimes have not been limited to the statute books. International criminal tribunals have encountered questions on the scope of culture and the operationalization of cultural rights on many occasions; and have made rather progressive contributions to the cultural rights discourse.

\section{A. Value-Oriented Approach}

What is particularly note-worthy about the way that culture has been captured and interpreted in international criminal trials is the attention to the value underlying the enjoyment of culture. Much like the HRC and Committee on Economic, Social, and Cultural Rights [CESCR], the ICTY, too, in its early jurisprudence, placed emphasis on the internationalist aspects of culture. In Prosecutor $v$. Kordic \& Čerkez, the ICTY found that wilful damage of institutions dedicated to Muslim religion or education constituted persecution as a crime against humanity because "all of humanity is indeed injured by the destruction of a unique religious culture and its concomitant cultural objects". ${ }^{33}$ This aligns with the value orientations associated with cultural rights under the ICESCR. Former UN Special Rapporteur on Cultural Rights Farida Shaheed was of the view that "access to and enjoyment of cultural heritage as a human right is a necessary and complementary approach to the preservation/ safeguard of cultural heritage". ${ }^{34}$ Because of the fixation with internationalism, culture-based crimes were confined to destruction of property and heritage. ${ }^{35}$

Nonetheless, a closer examination of the decisions of the ICTY reveals that these tribunals have adopted a more individualistic value of culture than what can be prima facie gleaned; it would not be wrong to argue that the ICTY has furthered interpretations of culture that are grounded in the dignity and agency of the victims. For instance, in Prosecutor $v$. Brđanin, the Appeals Chamber acknowledged Witness Kaiser's poignant statement that the destruction of culture was an attempt to dehumanize the victims. In the Witness's words, it was to send a message that “we don't respect you, we don't respect your system of belief, we don't respect your culture or psychology". ${ }^{6}$ This notion is more prominently endorsed in other cases. By way of illustration, the Trial Chamber in Prosecutor v. Prlic et al. recognized

32. ICTY Statute, supra note 30 , arts. $5(\mathrm{~h}), 4$; Rome Statute, supra note 24 , arts. 6, 7(h); Statute of the International Criminal Tribunal for Rwanda, SC Res. 955, UN Doc. S/RES/95 5 (I994), arts. 2, $3(\mathrm{~h})$; Law on the Establishment of the Extraordinary Chambers in the Courts of Cambodia for the Prosecution of Crimes Committed During the Period of Democratic Kampuchea, 27 October 2004, arts. 4, 5; Statute of the Special Court for Sierra Leone, SC Res. I3 I 5, UN Doc. S/RES/ I3 I 5 (2000), art. 2(h).

33. Prosecutor v. Kordic \& Cerkez, Trial Judgement, 26 February 200I, Case No. IT-95-I4/2-T at para. 207.

34. UN Human Rights Council, Report of the Independent Expert in the Field of Cultural Rights, Farida Shabeed, 2 I March 20II, UN Doc. A/HRC/I7/38, at para. 2.

35. Shea ESTERLING, "Exploring Culture in International Criminal Law Through The Prosecutor v. Ahmad Al Faqi Al Mahdi" Art and International Justice Initiative (4 July 2019), online: Art and International Justice Initiative <https://artij.org/en/blog.html\# I 4>.

36. Prosecutor v. Brdanin, Appeal Judgement, 3 April 2007, Case No. IT-99-36-A, at para. 338, n. 693. 
that the destruction of mausoleums violated Muslims' basic rights to "life, freedom and dignity". ${ }^{37}$ Similarly, the Trial Chamber in Prosecutor v. Kupreškic et al. cited Australian jurisprudence which found that all measures in disregard of human dignity may, in appropriate cases, constitute persecution. ${ }^{38}$ The value-oriented approach was most pronounced in the ICC's Prosecutor v. Al Mahdi ruling. The Prosecutor's opening statement included profound comments on how core crimes "inflict irreparable damage to the human persons in his or her body, mind, soul and identity". ${ }^{39}$ While some commentators warned that such an approach would require proof of human injury, ${ }^{40}$ the Court avoided falling into the bounds of anthropocentrism. Instead, it recognized that the diffusion of culture is "indispensable to the dignity of man". ${ }^{\mathrm{I}}$

\section{B. Scope of Culture and Array of Constitutive Rights}

It appears that the dignity-based interpretation of culture in international criminal law has had direct and visible effects on the ambit of culture itself. Notably, in Prosecutor $v$. Al Hassan, ${ }^{42}$ the Prosecutor acknowledged that culture encompassed "[p]rivate life, public life, leisure activities, cultural and religious practices, the manner of praying-absolutely everything, including the way people could dress". ${ }^{43}$ Consequently, the claim of persecution was grounded in the banning of religious holidays, of public gatherings, of ethnic clothing or jewellery, and even music. In its landmark Case No. 002 Judgment, the Extraordinary Chambers in the Courts of Cambodia found that the Cham workers were victims of persecution because they "were forced to eat pork, they were prevented from worshiping and speaking their native tongue". ${ }^{44}$ There are traces of such interpretations even in the Prosecutor $v$. Nabimana et al. ruling of the ICTR, where the Tribunal agreed that the nuances of the Kinyarwanda language form part of Tutsi culture. ${ }^{45}$

\section{Gravity of the Violation}

Prosecutor $v$. Al Mahdi was the first instance where a conviction was issued purely on the basis of a culture crime. Here, it is relevant to note that the Court admitted that

37. Prosecutor v. Prlić et al., Trial Judgement, 29 May 20I3, Vol. 3, Case No. IT-04-74-T, at para. I7 I 2.

38. Prosecutorv. Kupreškić et al., Trial Judgement, I4 January 2000, Case No. IT-95-I6-T, at para. 588, n. 857; Chan v. Minister for Immigration and Ethnic Affairs (1989) I69 CLR 379.

39. Statement of the Prosecutor of the International Criminal Court, Fatou Bensouda, at the Pre-Trial hearing phase in the case against Al Mahdi, I March 2016.

40. Marina LOSTAL, "Prosecutor v. Al Mahdi: A Positive New Direction for the ICC?" Opinio Juris (26 October 20I6), online: Opinio Juris <http://opiniojuris.org/20I6/Io/26/prosecutor-v-al-mahdi-apositive-new-direction-for-the-icc/>.

4I. Prosecutor v. Ahmad Al Faqi Al Mahdi, Judgement and Sentence, 27 September 20r6, Case No. ICC-оI/I 2-OI/I 5-I7I, Trial Chamber VIII, at para. 46.

42. Prosecutor v. Al Hassan Ag Abdoul Aziz Ag Mohamed Ag Mahmoud, 8 July 2or9, Case No. ICC-oI/I 2-or/I 8, Pre-Trial Chamber I.

43. Statement of the Prosecutor of the International Criminal Court, Fatou Bensouda, at the opening of the Confirmation of Charges hearing in the case against Al Hassan, 8 July 2019.

44. Case 002/02, Judgement, I6 November 2018, Case No. 002/19-09-2007/ECCC/TC, at para. I695.

45. Prosecutor v. Nahimana et al., Appeal Judgement, 28 November 2007, Case No. ICTR-99-52-A, at para. 700. 
crimes against property are inherently less grave compared to crimes against persons. Nonetheless, it took account of the symbolic value that the targeted buildings held for the inhabitants of Timbuktu. ${ }^{46}$ It also lent weight to the particularly insidious intent that motivated the destruction of the mausoleums-in that the Ansar Dine and AQIM sought to "impose their religious edicts on the population". ${ }^{47}$ In the ongoing case against Al Hassan, ${ }^{48}$ and in earlier cases such as Prosecutor $v$. Blaškic, ${ }^{49}$ the ICC and ICTY have also confirmed charges of crimes against humanity on the basis of violations of cultural rights. These findings confirm that cultural rights violations can by themselves constitute core crimes.

\section{Beneficiaries}

The ICC has recently begun endorsing collective reparations. Rule 98 of the ICC Rules of Procedure and Evidence specifies that the ICC may order reparations to be deposited with the Trust Fund for Victims when it is impossible or impracticable to make awards directly to each victim, or when the number of the victims and the scope and form of reparations makes a collective award more appropriate. ${ }^{50}$ The Court has actively applied this rule. Notably, in Prosecutor $v$. Lubanga, the Court awarded collective reparations to the tune of US\$ Io million. ${ }^{5 \mathrm{I}}$ While assessing which victims were eligible for reparations, it recognized that hundreds or thousands of victims were affected by Lubanga's crimes. ${ }^{52}$ The reparations were designed to be symbolic as well-the Chamber actually approved the building of three commemoration centres to serve as "living" spaces for symbolic activities. ${ }^{53}$ This was followed by the Prosecution v. Al Mabdi reparations order where the Trial Chamber found that the "that the harm caused by Mr Al Mahdi's actions [was] primarily collective in character". ${ }^{54}$ It further explained that the buildings belonged to everyone in Timbuktu and their loss was felt by the community as a whole. ${ }^{55}$ If we view the Court's acknowledgement that the entire community suffers an expressive harm upon the destruction of cultural heritage through the lens of Hohfeld's jural

\footnotetext{
46. Prosecutor v. Ahmad Al Faqi Al Mahdi, supra note 4I at para. 79.

47. Ibid., at para. $8 \mathrm{I}$.

48. "Al Hassan case: ICC Pre-Trial Chamber I Confirms Charges of War Crimes and Crimes against Humanity and Commits Suspect to Trial” International Criminal Court (30 September 2019), online: ICC <https://www.icc-cpi.int/Pages/item.aspx?name=prI483>.

49. Prosecutor v. Blaškić, Trial Judgement, 3 March 2000, Case No. IT-95-I4-T, at para. I 85.

50. Rules of Procedure and Evidence, 9 September 2002, rules 98(2) and 98(3), online: ICC <www.icccpi.int>.

5I. Prosecutor v. Thomas Lubanga Dyilo, Corrected Version of the "Decision Setting the Size of the Reparations Award for which Thomas Lubanga Dyilo is Liable”, 2I December 20I7, Case No. ICC-or/o4-or/o6-3379-Red-Corr-tENG, Trial Chamber II.

52. Ibid.

53. Prosecutor v. Thomas Lubanga Dyilo, Information Regarding Collective Reparations, I3 February 2017, Case No. ICC-oı/o4-or/o6-3273, Trial Chamber II, at para. I32.

54. Prosecutor v. Ahmad Al Faqi Al Mahdi, Reparations Order, I7 August 20I7, Case No. ICC-OI/ I2-OI/I 5-236, Trial Chamber VIII, at para. 76 .

55. Ibid., at para. 67 .
} 
relationships, ${ }^{56}$ this means that groups enjoy and exercise cultural rights collectively. Even if it is argued that Prosecution v. Al-Mahdi cannot serve as a justification for the entire array of cultural rights, the ICC's practice of material and symbolic collective reparations confirms that the right to remedy (in the form of restored cultural sites and access to cultural spaces) accrues to the whole group. This could only mean that the primary right to access culture itself accrues to the entire group.

\section{IMPLICATIONS FOR ASIA}

Since neither China nor India nor Myanmar has ratified the Optional Protocols to the ICESCR and ICCPR, the individual state complaints procedure under these regimes cannot be resorted to. There appear to be two main alternative avenues where these claims can be agitated. First, states that have accepted the competence of the HRC and CESCR to issue interstate communications or launch inquiry procedures can file complaints against defaulting states. ${ }^{57}$ Second, states can invoke the contentious jurisdiction of the International Court of Justice [ICJ]. ${ }^{58}$ However, China and Myanmar have not consented to the compulsory jurisdiction of the Court. Even India, despite having deposited an optional clause declaration, has a rather expansive set of reservations. ${ }^{59}$ Given these limitations, having resort to jurisdiction via a special agreement $^{60}$ appears to be most suitable.

\section{A. Normative Challenges}

Preliminarily, it is crucial to address whether the cross-fertilization of international criminal law and human rights law is normatively reconcilable. Evelyne Schmid partly addresses the normative challenges to such cross-fertilization in her book where she attempts to translate ECSR violations into crimes. ${ }^{6 \text { I }}$ Admittedly, international criminal law pursues multiple objectives, including de-legitimizing the context of violations, enabling fair and effective investigations and prosecutions, and providing some form of redress to victims. Not all of these objectives sit well with human rights law.

In comparison, it is easier to transpose international criminal law into human rights and public international law. Such inverse osmosis will allow courts and tribunals to take account of local interests in rehabilitation and reintegration in a manner

\footnotetext{
56. Wesley Newcomb HOHFELD, "Some Fundamental Legal Conceptions as Applied in Judicial Reasoning” (I9I3) 23 Yale Law Journal I6 at 29.

57. ICCPR, supra note $\mathrm{I} 7$, arts. 4I-3; Optional Protocol to the International Covenant on Economic, Social and Cultural Rights, GA Res. I I 7 (LXIII), UN Doc. A/RES/63/I I 7 (2009), art. Io.

58. Statute of the International Court of Justice, 26 June I945, U.S.T.S. 993 (entered into force 24 October 1945), arts. 36, 40 [Statute of the ICJ].

59. See list of declarations at <https://www.icj-cij.org/en/declarations>.

6o. Statute of the ICJ, supra note 58 , art. 40.

6I. Evelyne SCHMID, Taking Economic, Social and Cultural Rights Seriously in International Criminal Law (Cambridge: Cambridge University Press, 2015) at 452.
} 
that international criminal law does not fully accommodate. The ICJ, for one, has made efforts at unifying the international jurisprudence on genocide-in the Bosnian Genocide case, ${ }^{62}$ and in the case between Croatia and Serbia. ${ }^{63}$ As Judge Tomka noted in his Separate Opinion in the Bosnian Genocide case, "[ $\mathrm{t}$ ]he activity of the Court has thus complemented the judicial activity of the ICTY in fulfilling the Court's role in the field of State responsibility for genocide, over which the ICTY has no jurisdiction". ${ }^{64}$ Human rights courts, on the other hand, have not been as eager to cross-reference international criminal law. ${ }^{65}$ At best, the European Court of Human Rights has made references to the legal statutes or case-law of international criminal tribunals, in an attempt to outline comparative practice. ${ }^{66}$ More recently, the Court has begun relying on international criminal law to buttress its interpretation of foreseeability of crimes as under Article 7 of the European Convention on Human Rights. ${ }^{67}$ So long as such cross-referencing is not used as a proxy for independent substantive and factual determinations, institutional and methodological accommodation is desirable, and occasionally even necessary.

\section{B. Standing}

Rules of standing are particularly strict at the ICJ. According to the Articles on the Responsibility of States for Internationally Wrongful Acts [ARSIWA], in the absence of violations of bilateral treaty obligations, a state has the standing to agitate responsibility of another state for a wrongful act if the act in question violates an erga omnes obligation. $^{68}$

The fact that core crimes can be committed even exclusively on the basis of violations of cultural rights suggests that such rights are of a sufficiently serious character. The ICJ in the Nuclear Weapons and Wall Advisory Opinions observed that some rules of international humanitarian law "are so fundamental to the respect of the human person" that they are "intransgressible", suggesting that they are peremptory

62. Application of the Convention on the Prevention and Punishment of the Crime of Genocide (Bosnia and Herzegovina $v$. Serbia and Montenegro), Judgment, 26 February 2007, [2007] I.C.J. Rep. 43 at I66.

63. Application of the Convention on the Prevention and Punishment of the Crime of Genocide (Croatia v. Serbia), Judgment, 3 February 2015, [2015] I.C.J. Rep. 3 at $46-7$.

64. Application of the Convention on the Prevention and Punishment of the Crime of Genocide (Bosnia and Herzegovina v. Serbia and Montenegro), Judgment, 26 February 2007, Separate Opinion of Judge Tomka, [2007] I.C.J. Rep. 43 at $35 \mathrm{I}$.

65. Patricia P. SOARES and Gerhard KREUTZER, "Catalytic, Gap-Filling, or Retardant Effects of ICL on HRL: Quid Juris" in Paul De HERT, Stefaan SMIS, and Mathias HOLVOET, eds., Convergences and Divergences Between International Human Rights, International Humanitarian and International Criminal Law (Cambridge/Antwerp/Poland: Intersentia, 2018), 3 at 9.

66. Babar Ahmad and Others v. United Kingdom, Judgement of Io April 20I2, ECHR, App. Nos. 24027/07, I I949/08, 36742/08, 669II/09, and 67354/09, at para. I40.

67. Vasiliauskas v. Lithuania, Judgement of 20 October 201 5, ECHR Grand Chamber, App. No. $35343 /$ 05, at paras. I 53-9I.

68. Draft Articles on Responsibility of States for Internationally Wrongful Acts, with commentaries, Report of the International Law Commission on the Work of its Fifty-Third Session (23 April-I June and 2 July-Io August 200I), U.N.Doc. A/56/IO (IV.E.2) (200I), arts. 42(b)(i), 48. 
norms. ${ }^{69}$ As Dire Tladi explains, all peremptory norms are accompanied by erga omnes obligations, in that they allow all members of the international community to enforce state responsibility for such acts. ${ }^{70}$ Moreover, scholars like Bellamy ${ }^{7 \mathrm{I}}$ and Strauss ${ }^{72}$ confirm that egregious violations of humanitarian law amounting to war crimes and crimes against humanity create erga omnes obligations considering that these crimes seek to secure fundamental human rights and humanitarian principles.

When applied to the conflicts in Asia, this means that the cumulative and serious violations of cultural rights can potentially be violations of erga omnes obligations to secure and ensure respect for human rights. Admittedly, this line of argument is more appropriate for situations of international or internal armed conflicts-where cultural rights violations are often disguised as war crimes. Alternatively, as Joanne Lee argues, the case-law of international criminal tribunals suggests that the crime of persecution-even of cultural rights-constitutes a violation of the right to selfdetermination. ${ }^{73}$ In the Chagos Islands Advisory Opinion, the ICJ observed that "[s]ince respect for the right to self-determination is an obligation erga omnes, all States have a legal interest in protecting that right" ${ }^{74}$ Applying this finding, states can agitate responsibility for cultural rights violations against the Asian states that are the subject of this study.

\section{Nature of Violation}

Once an erga omnes obligation is invoked, the next step is to prove a violation of an international legal obligation. In other words, to prove that cultural rights were indeed infringed. The jurisprudence of the ICC, ICTY, and ICTR discussed above highlights that when grounded in dignity and diversity, the right to culture acquires an expansive meaning. It encompasses linguistic freedom, freedom of cultural association, the right to access traditional lands, the right to ethnic clothing, the right to practise religion, the right to cultural heritage, and the right to celebrate festivals of one's choice. The conflicts in Myanmar, India, and China each assault at least one of these rights. In China, the Uighurs are allegedly being forced to learn Chinese, and denounce their language and religion. There are also reports of mosques being

69. Legality of the Threat or Use of Nuclear Weapons, Advisory Opinion, 8 July I996 [I996] I.C.J. Rep. 226 at 257, para. 79; Legal Consequences of the Construction of a Wall in the Occupied Palestinian Territory, Advisory Opinion, 9 July 2004 [2004] I.C.J. Rep. I 36 at I99, paras. I55, I 57.

70. Fourth Report on Peremptory Norms of General International Law (jus cogens) by Dire Tladi, Special Rapporteur, International Law Commission, UN Doc. A/CN.4/727 (20I9).

7I. Alex J. BELLAMY, Sara E. DAVIES, and Luke GLANVILLE, eds., The Responsibility to Protect and International Law (Leiden/Boston: Martinus Nijhoff Publishers, 20I I) at 9I-2.

72. Ekkehard STRAUSS, "A Bird in the Hand Is Worth Two in the Bush: On the Assumed Legal Nature of the Responsibility to Protect” in Bellamy et al., ibid., at 49.

73. Joanne E. LEE, The Right to Self-Determination: An International Criminal Law Perspective, The University of British Columbia, Theses and Dissertations (2000), online: UBC <https://open.library. ubc.ca/cIRcle/collections/ubctheses/83 I/items/I.0077436>.

74. Legal Consequences of the Separation of the Chagos Archipelago from Mauritius in I965, Advisory Opinion, 25 February 20I9, I.C.J. G.L. No I69, I.C.G.J. 534 (ICJ 20I9), at para. I80. 
demolished. In Myanmar, the Rohingyas have been displaced from their ancestral lands. In India, the Union government removed Muslim holidays from the list of public holidays. According to studies by independent media outlets, over I40 Muslims have been killed in mob violence in India since 2015 (soon after the right-wing Hindu ruling party assumed office)-because they eat beef, which is considered sacrilegious in Hinduism. ${ }^{75}$ Using findings from international criminal law, states can claim that such acts-infringements of linguistic freedom, freedom of association, right to access traditional land, right to enjoy customs-are violations of cultural rights.

\section{CONCLUSION}

Cultural rights delicately straddle human rights law and penal law. In the essentially ethnic conflicts that have shrouded Asia, cultural rights appear to be both timely and desirable in the way that they secure the freedom to express ethnic identities. However, cultural rights have been almost deliberately ignored in order not to legitimize the counter-authoritarian narrative. Asian states have even guaranteed immunity to state actors by declining to opt into human rights or international criminal law enforcement mechanisms. But that is not reason enough to ignore the serious and evident violations of human rights that such states have perpetrated. Therefore, it is imperative that the osmosis between human rights law and international criminal law be actively encouraged; that human rights and international criminal law jurisprudence be synthesized so that the existing toolbox in international criminal law can be used to give effect to the objectives of human rights law.

75. Conclusion derived from "Lynchistan: Mob Lynching Cases Across India" The Quint, online: The Quint <https://www.thequint.com/quintlab/lynching-in-india/>, and "The High Cost of Targeted Violence in Northeast Delhi: A List of the Deceased" The Polis Project (I 8 March 2020), online: The Polis Project <https://www.thepolisproject.com/the-high-cost-of-targeted-violence-in-northeast-delhi-a-list-of-the-deceased/\#.XtzQ6GgzbIV>. 